\title{
PROFITABILITAS, CORPORATE GOVERNANCE, UKURAN PERUSAHAAN DAN INTENSITAS MODAL TERHADAP PENGHINDARAN PAJAK
}

\author{
Lustina Rima Masrurroch ${ }^{(1)}$
}

Program Studi Akuntansi, Fakultas Ekonomi, Universitas Islam Batik Surakarta

lustinarimam@gmail.com

\begin{tabular}{|l|l|l} 
Diterima : bulan, tahun & Direvisi : bulan, tahun & Diterbitkan : bulan, tahun \\
\hline
\end{tabular}

\begin{abstract}
This study aims to analyze the effect of profitability, corporate governance, firm size, and capital intensity on tax avoidance in property and real estate companies listed on the Indonesia Stock Exchange for the period 20162018. Corporate governance in this study uses leverage variables and independent commissioners. The population of this study is 54 property and real estate companies listed on the Indonesia Stock Exchange for the period 20162018. Determination of samples using purposive sampling method and obtaining 23 companies with certain criteria. The analysis technique used in this study is multiple linear regression. The results showed that the profitability and firm size variables had a significant negative effect on tax avoidance, while the leverage variable, independent commissioner, and capital intensity did not affect tax avoidance.
\end{abstract}

Keywords : Profitabilitas, Corporate Governance, Firm Size, Capital Intensity, Tax Avoidance

\begin{abstract}
Abstrak : Penelitian ini bertujuan untuk menganalisis pengaruh profitabilitas, corporate governance, ukuran perusahaan dan intensitas modal terhadap penghindaran pajak pada perusahaan property dan real estate yang terdaftar di Bursa Efek Indonesia periode 2016-2018. Corporate governance dalam penelitian ini menggunakan variabel leverage dan komisaris independen. Populasi penelitian ini sejumlah 54 perusahaan property dan real estate yang terdaftar di Bursa Efek Indonesia periode 2016-2018. Penentuan sampel dengan menggunakan metode purposive sampling dan memperoleh 23 perusahaan dengan kriteria tertentu. Teknik analisis yang digunakan dalam penelitian ini adalah regresi linear berganda. Hasil penelitian menunjukkan bahwa variabel profitabilitas dan ukuran perusahaan berpengaruh negatif signifikan terhadap penghindaran pajak, sedangkan variabel leverage, komisaris independen, dan intensitas modal tidak berpengaruh terhadap penghindaran pajak.
\end{abstract}

Kata kunci : Profitabilitas, Corporate Governance, Ukuran Perusahaan, Intensitas Modal, Penghindaran Pajak.

\section{A. Latar Belakang}

\section{Permasalahan Penelitian}


Pajak merupakan sumber utama bagi pendapatan negara Indonesia untuk menunjang pembiayaan dan pembangunan nasional. Dengan demikian masyarakat Indonesia mempunyai kewajiban untuk membayar pajak kepada pemerintah. Pajak merupakan suatu kewajiban atau beban yang harus dipenuhi kewajibannya oleh wajib pajak orang pribadi maupun perusahaan. Pajak memiliki kontribusi yang cukup tinggi dalam penerimaan pendapatan negara (APBN). Menurut Undang-Undang Nomor 16 tahun 2009 tentang Ketentuan Umum dan Tata Cara Perpajakan pada Pasal 1 ayat 1 menjelaskan bahwa pajak merupakan kontribusi wajib kepada negara yang terutang oleh orang pribadi atau badan yang bersifat memaksa berdasarkan undang-undang dengan tidak mendapatkan imbalan secara langsung dan digunakan untuk keperluan negara demi kemakmuran rakyat. Pajak merupakan sumber penerimaan negara yang paling potensial dan menempati persentase tertinggi dalam Anggaran Pendapatan dan Belanja Negara (APBN) dibandingkan penerimaan dari sektor lainnya. Jika pajak menjadi sumber pendapatan utama bagi negara, lain halnya bagi perusahaan yang menganggap pajak merupakan beban yang akan mengurangi laba bersih mereka Ariawan (2017).

Waluyo (2011) menyatakan bahwa cara menggambarkan kemandirian negara Indonesia adalah dengan mencari sumber dana dari pajak. Sedangkan menurut Imam dan Ning (2013) berpendapat bahwa sebagian besar perusahaan sebagai wajib pajak menilai bahwa pembayaran pajak merupakan beban, karena sumber pajak adalah perubahan dari sektor bisnis atau perusahaan ke sektor bisnis atau pemerintah atau pemerintah yang mempengaruhi ketaatan wajib pajak menurun. Dengan adanya perbedaan kepentingan tersebut maka wajib pajak cenderung mengurangi pembayaran pajak secara legal maupun ilegal. Penghindaran pajak secara legal diartikan sebagai tax avoidance yang merupakan cara perusahaan melakukan pengurangan beban pajak sekecil mungkin tanpa melanggar Undang-Undang yang berlaku.

Perbedaan kepentingan antara perusahaa dengan pemerintah menjadi persoalan yang rumit di Indonesia di mana perusahaan menginginkan pembayaran pajak sekecil mungkin tanpa melanggar Undang-Undang yang berlaku. Dalam kegiatan penghindaran pajak memiliki beberapa faktor penyebab, yang pertama adalah profitabilitas. Menurut Rodriguez dan Arias (2013) profitabilitas sebagai penentu beban pajak, di mana perusahaan yang berlaba besar mampu taat membayar pajak setiap tahun sedangkan perusahaan yang berlaba sedikit dan mengalami kerugian akan membayar pajak sedikit.

Faktor kedua yaitu, corporate governance. Corporate governance adalah tata kelola perusahaan untuk menentukan arah kinerja perusahaan menjadi lebih baik sesuai peraturan dari pemerintah. Maharani dan 
Suardana (2014) berpendapat, corporate governance belum sepenuhnya dilaksanakan oleh perusahaan terbukti dari banyaknya perusahaan yang mempraktikkan penghindaran pajak. Terkait dengan corporate governance penelitian ini menggunakan leverage dan komisaris independen sebagai proksi. Leverage merupakan tingkat risiko perusahaan yang diukur dari perbandingan antara total hutang dengan total modal perusahaan. Komisaris independen mempunyai pengaruh dalam pengarahan perusahaan untuk melakukan praktik penghindaran pajak atau tidak.

Faktor ketiga adalah ukuran perusahaan yang mampu menunjukkan kemampan serta kestabilan perusahaan dalam menjalakan aktivitas ekonomi. Semakin besar ukuran perusahaan maka semakin rendah beban pajaknya dan perusahaan akan mampu membuat perencanaan yang baik dengan menggunakan sumber daya yang dimiliki. Sedangkan untuk perusahaan yang berukuran kecil maka semakin sedikit dan terbatas dalam melakukan praktik penghindaran pajak. Faktor keempat yaitu intensitas modal, yang didefinisian sebagai perusahaan yang melakukan penginvestasian terhadap asetnya menjadi aset tetap dan persediaan.

Dari beberapa latar belakang di atas maka peneliti akan menguji kembali terkait dengan faktor-faktor penyebab penghindaran pajak yang telah disebutan di atas. Penelitian ini mempunyai perbedaan dengan penelitian sebelumnya terkait dengan obyek penelitian yaitu pada perusahaan property dan real estate.

\section{Tinjauan Pustaka}

\section{Teori Agensi}

Teori agensi menjelaskan hubungan antara pihak-pihak yang memberikan wewenang (pokok) dan menerima otoritas (agen). Luayyi (2010) di Yulfaida dan Zulaikha (2012) menyatakan bahwa teori keagenan pada dasarnya membahas bentuk kesepakatan antara pemilik modal dan manajer untuk mengelola perusahaan.

Manajer tidak selalu bertindak dengan keinginan terbaik dari pemegang saham karena pilihan terburuk atau adanya moral hazard. Disamping itu, juga dapat terjadi adanya asimetri informasi dan manajemen laba. Menurut Anthony (2005) teori agensi merupakan teori yang menghubungkan dua pemangku kepentingan dan beranggapan bahwa setiap individu semata-mata termotivasi oleh kepentingan sehingga terjadi konflik kepentingan antara principal dan agent.

Dalam hal ini dengan adanya pendelegasian wewenang kepada agent akan menyebabkan manajemen memiliki informasi nyata keadaan perusahaan yang lebih banyak dibandingkan dengan principal. Konflik tersebut mendasari pemikiran mengenai corporate governance selaku 
agent pada teori agensi yang harus dikendalikan oleh principal untuk memastikan bahwa pengelolaan perusahaan dilakukan dengan penuh kepatuhan terhadap peraturan dan ketentuan yang berlaku termasuk dalam hal perpajakan Intan (2018).

\section{Penghindaran Pajak}

Penghindaran pajak dilakukan oleh wajib pajak untuk mengurangi pembayaran pajak sekecil mungkin tanpa melanggar peraturan pemerintah. Penghindaran pajak dilakukan secara legal oleh wajib pajak orang pribadi maupun badan yang mempunyai usaha dalam mengoptimalkan beban pajak sekecil mungkin dengan tidak melanggar undang-undang yang berlaku. Penghindaran pajak dalam penelitian ini menggunakan beban pajak penghasilan dibagi dengan laba sebelum pajak penghasilan dalam Lanis dan Richardson (2011). Dalam penelitian ini menggunakan beban pajak penghasilan dibagi dengan laba sebelum pajak penghasilan untuk menghitung penghindaran pajak. Berikut rumus menghitung CETR :

\section{CETR =}

Total beban pajak penghasilan

\section{Profitabilitas}

Profitabilitas didefinisikan sebagai seberapa besar kemampuan perusahaan dalam memperoleh laba. Rasio untuk mengukur profitabilitas dalam penelitian ini menggunakan return on asset, pengukuran ini digunakan untuk mengetahui bagaimana kemampuan perusahaan dalam memanfaatkan asetnya untuk memperoleh keuntungan. Profitabilitas perusahaan dapat diukur menggunakan rasio return on asset. Menghitung ROA dengan menggunakan laba bersih setelah pajak dibagi dengan seluruh total aktiva.

Apabila tingkat profitabilitas perusahaannya tinggi, maka semakin besar laba yang dihasilkan perusahaan dalam bentuk dividen kepada pemegang saham. Profitabilitas yaitu kemampuan perusahaan dalam memperoleh laba bersih dari kegiatan operasionalnya. ROA dapat menunjukkan kemampuan perusahaan dengan memperoleh keuntungan dari asset atau aktiva yang digunakan. Dividen yaitu laba bersih yang diperoleh perusahaan, karena itu dividen akan dibagikan jika perusahaan memperoleh keuntungan. Berikut adalah rumus perhitungan ROA :

\section{ROA $=\frac{\text { Laba bersih }}{\text { Total Aset }}$}

\section{Corporate Governance}


Corporate Goverance didefinisikan sebagai sistem dalam mengarahkan mengelola urusan- urusan bisnis perusahaan, dan menjamin terpenuhinya kewajiban perusahaan dalam rangka meningkatkan kemakmuran bisnis dan akuntabilitas perusahaan dalam jangka panjang dan tetap memperhatikan kepentingan stakeholders lain. Corporate Goverance dalam penelitian ini diukur menggunakan.

\section{Leverage}

Leverage adalah rasio yang menggambarkan seberapa besar perusahaan didanai oleh pihak luar. Kurniasih et al (2013) menyatakan leverage merupakan rasio yang digunakan untuk mengukur kemampuan hutang baik jangka panjang maupun jangka pendek untuk membiayai aktiva perusahaan. Sesuai dalam penelitian Kurniasih (2013) variabel leverage di ukur dengan Total (DER) Debt to Equity. DER yaitu ratio yang digunakan untuk menunjukkan kemampuan dalam memenuhi seluruh kewajiban yang ditunjukkan oleh beberapa modal sendiri yang digunakan untuk membayar hutang (Jalung, 2017). DER yaitu membandingkan antara total liabilitas dengan total ekuitas. Rasio menunjukkan bahwa sejauh mana total sendiri menjamin semua utang. Apabila DER tinggi berarti perusahaan sudah melaksanakan pembiayaan yang agresif sehingga perusahaan tersebut tumbuh bersamaan dengan utangnya. Semakin besar DER berarti semakin besar pula ketergantungan perusahaan terhadap pihak eksternal (kreditur) maka semakin besar pula perusahaan harus membayar beban biaya hutangnya. Peningkatan hutang ini akan mempengaruhi besar kecilnya laba bersih bagi pemegang saham termasuk dividen yang akan diterima. Berikut adalah rumus perhitungan DER :

DER $=\frac{\text { Total Liabilitas }}{\text { Total Ekuitas }}$

\section{Komisaris Independen}

Komisaris independen merupakan dewan yang mengawasi suatu perusahaan agar mematuuhi hukum dan peraturan yang berlaku sebagaimana mestinya. Dewan komisaris independen dipilih oleh RUPS (Rapat Umum Pemegang Saham) dan tidak memiliki hubungan afiliasi dengan direksi maupun dewan komisaris serta tidak menjabat sebagai direktur pada suatu perusahaan. Pengukuran variabel komisaris independen yaitu :

$$
\mathrm{KI}=\frac{\text { Jumlah Komisaris Independen }}{\text { Total Komisaris }}
$$

\section{Total Komisaris}

\section{Ukuran Perusahaan}

Ukuran Perusahaan merupakan skala yang yang digunakan untuk 
menggambarkan besar kecilnya perusahaan yang dilihat berdasarkan total aset yang dimiliki perusahaan. Menurut Ardi dan Lana (2007) ukuran perusahaan sangat berpengaruh pada tiga faktor yaitu, besarnya total aktiva, besarnya hasil penjualan, dan besarnya kapitalisasi pasar. Pengukuran variabel ukuran perusahaan dalam penelitian ini dengan menggunakan total aset, dengan cara me-logaritma total asset yang dimiliki oleh perusahaan.

\section{Intensitas Modal}

$$
S I Z E=\operatorname{Logn}(\text { total aset })
$$

Intensitas Modal dalam penelitian ini dikaitkan dengan aset tetap. Dharma dan Ardiana (2016) menyatakan intensitas modal menggambarkan seberapa besar perusahaan dalam menginvestasikan aset yang dimiliki pada aset tetap. Penyusutan intensitas modal dalam penelitian ini diukur menggunakan rasio intensitas aset tetap. Menurut Wijayanti et al (2017) rasio intensitas aset tetap adalah perbandingan total aset tetap terhadap total aset yang dimiliki perusahaan.

Intensitas

Modal =
Total Aset Tetap

Total Aset

\section{Kerangka Pemikiran}

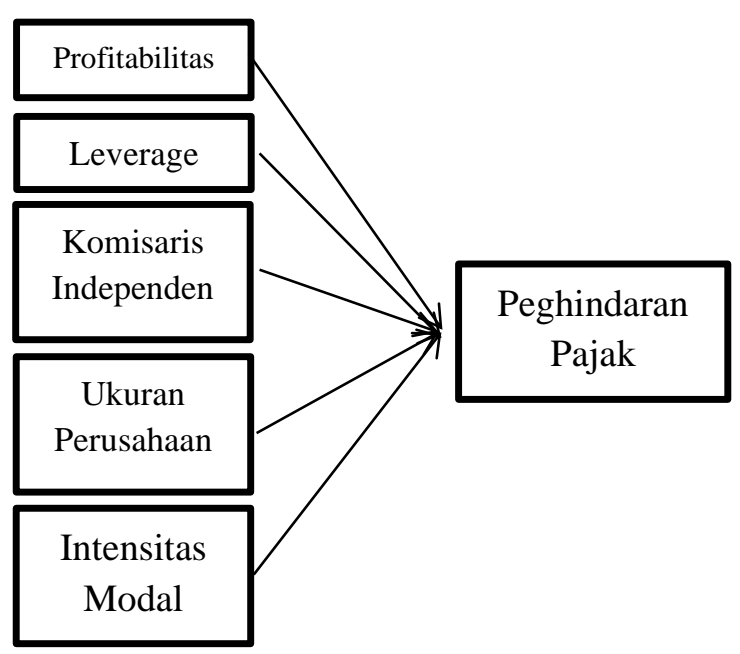

Gambar 1 Kerangka Pemikiran

\section{Hipotesis}

\section{1) Pengaruh Profitabilitas terhadap Penghindaran Pajak}

Penelitian yang dilakukan Darmawan dan Sukartha (2014) menyatakan ROA berpengaruh terhadap penghindaran pajak, yang berarti ketika laba yang diperoleh membesar, maka jumlah pajak penghasilan akan meningkat sesuai dengan peningkatan laba perusahaan. Hasil peneltian sejalan dengan Surbakthi (2012) yang meyatakan profitabilitas perusahaan dengan 
penghindaran pajak akan memiliki hubungan yang positif dan apabila perusahaan ingin melakukan penghindaran pajak, maka harus semakin efesiensi dari segi beban sehingga tidak perlu membayar pajak dalam jumlah besar. Dari simpulan hipotesis ketiga maka diambil hipotesis sebagai berikut :

H1: Profitabilitas berpengaruh terhadap penghindaran pajak.

2) Leverage Terhadap Penghindaran Pajak

Penelitian Rachmithasari dan Annisa (2015) memberikan bukti bahwa perusahaan yang memiliki kewajiban pajak tinggi akan memilih untuk berutang agar mengurangi pajak. Perusahaan yang memiliki nilai rasio leverage yang tinggi menunjukkan semakin tinggi jumlah pendanaan dari utang pihak ketiga luar yang digunakan perusahaan dan semakin tinggi pula biaya bunga yang timbul dari utang tersebut. Biaya bunga yang semakin tinggi akan memberikan pengaruh berkurangnya laba yang dapat mengurangi beban pajak perusahaan. Berdasarkan uraian diatas maka diambil hipotesis sebagai berikut :

H2 : Leverage berpengaruh terhadap penghindaran pajak.

3) Komisaris Independen Terhadap Penghindaran Pajak

Komisaris independen menurut Milhanudin (2017) memiliki fungsi untuk mengawas dan mengarahkan kebijakan perusahaan apakah perusahaan tersebut sudah memenuhi ketentuan-ketentuan yang berlaku. Penelitian yang dilakukan Putra dan Merkusiwati (2016) menyatakan bahwa komisaris independen berpengaruh positif terhadap penghindaran pajak. Yang artinya semakin banyak jumlah komisaris independen maka kemungkinan akan meningkatkan terjadinya penghindaran pajak. Berdasarkan uraian diatas maka diambil hipotesis sebagai berikut :

H3 : Komisaris Independen berpengaruh terhadap penghindaran pajak.

4) Ukuran Perusahaan Terhadap Penghindaran Pajak

Ukuran perusahaan menunjukkan kestabilan dan kemampuan perusahaan untuk melakukan aktivitas ekonominya. Hasil dalam penelitian yang dilakukan oleh Rodriguez dan Arias (2013) yang membuktikan bahwa ukuran perusahaan memiliki pengaruh positif dan signifikan terhadap penghindaran pajak. Ukuran perusahaan berhubungan dengan aset, semakin besar suatu perusahaan cenderung mempunyai aset yang besar dan semakin besar aset setiap tahunnya akan mengalami penyusutan dan menguragi laba bersih perusahaan, sehingga beban pajak yang dibayarkan makin kecil. Dari uraian diatas maka dapat diambil hipotesis pertama yaitu:

H4 : Ukuran perusahaan berpengaruh terhadap penghindaran pajak.

5) Intensitas Modal Terhadap Penghindaran Pajak

Hasil penelitian yang dilakukan Anindyka et al (2018) menemukan bahwa intensitas aktiva tetap memiliki pengaruh positif pada penghindaran pajak yang berarti semakin besar intensitas modal yang dimiliki perusahaan maka semakin besar pula perusahaan melakukan penghindaran pajak, karena perusahaan yang memiliki aset tetap akan terdapat beban 
penyusutan atau beban depresiasi yang dapat menjadi pengurang laba sebelum pajak. Maka dengan begitu perusahaan akan memanfaatkan aset tetap untuk meminimalkan beban pajak dengan cara menginvestasikan aset tetap pada perusahaan. Penelitian ini sesuai dengan penelitian Dharma dan Noviari (2017) yang menyatakan bahwa intensitas modal berpangaruh positif terhadap penghindaran pajak. Berdasarkan uraian diatas maka dapat diambil hipotesis sebagai berikut :

H5 : Intensitas Modal berpengaruh terhadap penghindaran pajak.

\section{Metode}

Penelitian ini merupakan penelitian deskriptif kuantitatif dengan menggunakan analisis data dengan karakteristik statistik untuk menguji hipotesis. Penelitian kuantitatif adalah penelitian yang dapat dihitung yang berhubungan dengan angka serta bertujuan untuk mengetahui seberapa besar variabel dependen mempengaruhi variabel independent. Ghozali (2006). Data dalam penelitian ini adalah data perusahaan property dan real estate. Data perusahaan property dan real estate didapat dari dokumentasi laporan keuangan perusahaan yang diakses dari www.idx.co.id. Data berupa annual report perusahaan yang terdaftar di Bursa Efek Indonesia selama periode 2016-2018. Kriteria yang diganakan dalam penelitian ini antara lain :

1) Perusahaan property dan real estate yang terdaftar dalam Bursa Efek Indonesia selama 3 tahun berturut-urut dalam periode tahun 20162018.

2) Perusahaan property dan real estate yang menyampaikan annual report perusahaan setiap tahun berturut-urut dalam periode tahun 2016-2018.

3) Perusahaan property dan real estate yang menyampaikan annual report perusahaan dalam mata uang rupiah.

4) Perusahaan property dan real estate yang memiliki laba positif selama periode tahun 2016-2018.

5) Perusahaan property dan real estate yang menyampaikan annual report perusahaan secara lengkap dan sesuai dengan kriteria yang diambil dalam penelitian ini.

Pengolahan data dalam penelitian ini menggunakan program IBM SPSS versi 21 untuk pengambilan keputusan penelitian. Metode analisis data dalam penelitian ini menggunakan metode analisis linear berganda. Analisis ini digunakan untuk mengetahui pengaruh profitabilitas, leverage, komisaris independen, ukuran perusahaan dan intensitas modal terhadap penghindaran pajak pada perusahaan property dan real estate. Dalam uji analisis linier berganda terdapat berbagai uji yaitu uji asumsi klasik, uji analisis regresi, uji ketepatan model dan uji koefisien determinasi. Berikut adalah gambaran persamaan linier berganda yang digunakan pada penelitian ini : 


$$
\mathrm{Y}=\mathrm{a}+\mathrm{b}_{1} \mathrm{X}_{1}+\mathrm{b}_{2} \mathrm{X}_{2}+\mathrm{b}_{3} \mathrm{X}_{3}+\mathrm{b}_{4} \mathrm{X}_{4}+\mathrm{b}_{5} \mathrm{X}_{5}+\mathrm{e}
$$

Keterangan :

\begin{tabular}{|c|c|}
\hline Y & $=$ Penghindaran Pajak \\
\hline$a$ & $=$ Konstanta \\
\hline $\mathrm{X}_{1}$ & $=$ Profitabilitas \\
\hline $\mathrm{X}_{2}$ & $=$ Leverage \\
\hline $\mathrm{X}_{3}$ & $=$ Komisaris Independen \\
\hline $\mathrm{X}_{4}$ & $=$ Ukuran Perusahaan \\
\hline $\mathrm{X}_{5}$ & $=$ Intensitas Modal \\
\hline$b_{1} b_{2} b_{3} b_{4} b_{5}$ & $\begin{array}{l}=\text { Koefisien Regresi } \\
=\text { Error }\end{array}$ \\
\hline
\end{tabular}

\section{B. Hasil dan Pembahasan}

Tabel 1

Kriteria Sampel

\begin{tabular}{c|l|c}
\hline No. & \multicolumn{1}{|c}{ Kriteria Sampel } & Jumlah Perusahaan \\
\hline 1. & $\begin{array}{l}\text { Perusahaan property dan real estate yang } \\
\text { terdaftar dalam Bursa Efek Indonesia selama 3 } \\
\text { tahun berturut-urut dalam periode tahun 2016- } \\
2018 .\end{array}$ & 41 \\
\hline 2. & $\begin{array}{l}\text { Perusahaan property dan real estate yang tidak } \\
\text { menyampaikan annual report perusahaan dalam } \\
\text { mata uang rupiah. }\end{array}$ & 0 \\
\hline 3. & $\begin{array}{l}\text { Perusahaan property dan real estate yang tidak } \\
\text { memiliki laba positif selama periode tahun 2016- } \\
\text { 2018. }\end{array}$ & $(10)$ \\
\hline 4. & $\begin{array}{l}\text { Perusahaan property dan real estate yang tidak } \\
\text { menyampaikan annual report perusahaan secara } \\
\text { lengkap dan sesuai dengan kriteria yang diambil } \\
\text { dalam penelitian. }\end{array}$ & $(8)$ \\
\hline \multicolumn{1}{c}{ Total Perusahaan } & 23 \\
\hline \multicolumn{1}{|c}{ Jumlah Observasi ( 23 x 3 ) } & $\mathbf{6 9}$ \\
\hline
\end{tabular}

Tabel 2

Uji Normalitas

\begin{tabular}{c|c|c|c}
\hline Variabel & Sig. & Syarat & Ketentuan \\
\hline $\begin{array}{c}\text { Unstandarized } \\
\text { Residual }\end{array}$ & 0.956 & $>0.05$ & $\begin{array}{c}\text { Terdistribusi } \\
\text { Normal }\end{array}$ \\
\hline
\end{tabular}

Sumber : data diolah (2019) 
Dari data tabel 2 di atas menunjukkan nilai signifikansi sebesar 0.956. Karena nilai signifikansi lebih besar daripada 0.05 , maka nilai residual terdistribusi dengan normal.

Tabel 3

Uji Multikolinieritas

\begin{tabular}{c|c|c|c|c|c}
\hline Variabel & Tolerance & Syarat & VIF & Syarat & Keputusan \\
\hline Profitabilitas & 0.923 & $>0.1$ & 1.083 & $<10$ & Tidak terjadi multikolinieritas \\
\hline Leverage & 0.757 & $>0.1$ & 1.322 & $<10$ & Tidak terjadi multikolinieritas \\
\hline Komisaris Independen & 0.944 & $>0.1$ & 1.059 & $<10$ & Tidak terjadi multikolinieritas \\
\hline Ukuran Perusahaan & 0.898 & $>0.1$ & 1.113 & $<10$ & Tidak terjadi multikolinieritas \\
\hline Intensitas Modal & 0.795 & $>0.1$ & 1.259 & $<10$ & Tidak terjadi multikolinieritas \\
\hline
\end{tabular}

Dari hasil tabel di atas dapat diketahui bahwa nilai Tolerance semua variabel lebih dari 0,10 dan VIF kurang dari 10. Maka dapat disimpulkan bahwa tidak terjadi multikolinieritas antar variabel tersebut.

Tabel 4

Uji Autokorelasi

\begin{tabular}{c|c|c|c|c|c}
\hline DW & dL & dU & 4-dL & 4-dU & Keputusan \\
\hline 1.966 & 1.4588 & 1.7680 & 2.232 & 2.5412 & $\begin{array}{l}\text { Tidak terjadi } \\
\text { autokorelasi }\end{array}$ \\
\hline
\end{tabular}

Dari data tabel di atas diketahui nilai Durbin-Watson sebesar 1,966. Karena nilai DW terletak antara DU dan 4-DU $(1.7680<1.966<2.232)$, maka kesimpulan dari uji autokorelasi tersebut adalah tidak terjadi autukorelasi pada model regresi.

Tabel 5

Uji Heteroskedastisitas

\begin{tabular}{l|c|c|c}
\hline \multicolumn{1}{c|}{ Variabel } & Sig. & Syarat & Keputusan \\
\hline Profitablitas & 0.684 & $>0.05$ & Bebas dari heteroskedastisitas \\
\hline Leverage & 0.674 & $>0.05$ & Bebas dari heteroskedastisitas \\
\hline Komisaris Independen & 0.113 & $>0.05$ & Bebas dari heteroskedastisitas \\
\hline Ukuran Perusahaan & 0.152 & $>0.05$ & Bebas dari heteroskedastisitas \\
\hline Intensitas Modal & 0.244 & $>0.05$ & Bebas dari heteroskedastisitas \\
\hline
\end{tabular}

Dari data tabel di atas menunjukkan bahwa nilai signifikansi dari semua variabel > 0.05 sehingga disimpulkan bahwa tidak terjadi masalah heteroskedatisitas dalam penelitian ini.

Tabel 6

Uji Analisi Regresi Linear Berganda

\begin{tabular}{l|c}
\hline \multicolumn{1}{c|}{ Variabel } & B \\
\hline Constant & -.219 \\
\hline Profitabilitas & .069 \\
\hline
\end{tabular}




\begin{tabular}{l|c}
\hline Leverage & -.011 \\
\hline Komisaris Independen & .087 \\
\hline Ukuran Perusahaan & .017 \\
\hline Intensitas Modal & -.219 \\
\hline
\end{tabular}

Sumber : Data diolah (2019)

Dari hasil uji tabel di atas maka diperoleh persamaan regresi linier berganda yaitu

$\mathrm{Y}=-0.219+-0.069+-0.011+0.087+-0.219+0.017+\mathrm{e}$

Dari model persamaan regresi linier tersebut maka diperoleh pengertian apabila konstanta bernilai -0.219 berarti variabel independen lainnya bernilai 0, maka variabel Y mengalami kenaikan sebesar 0.219 satuan. Koefisien regresi Profitabilitas bernilai 0.069 yang artinya apabila variabel Leverage, Komisaris Independen, Ukuran Perusahaan dan Intensitas Modal tetap dan Profitabilitas mengalami penambahan satu satuan maka variabel penghindaran pajak akan mengalami penurunan sebanyak 0.069. Koefisien regresi Leverage bernilai -0.011 yang artinya apabila variabel Profitabilias, Komisaris Independen, Ukuran Perusahaan dan Intensitas Modal tetap dan Profitabilitas mengalami penurunan satu satuan maka variabel penghindaran pajak akan mengalami penurunan sebanyak -0.011. Koefisien regresi Komisaris Independen bernilai 0.087 yang artinya apabila variabel Profitabilitas, Leverage, Ukuran Perusahaan dan Intensitas Modal tetap dan Komisaris Independen mengalami kenaikan satu satuan maka variabel penghindaran pajak akan mengalami kenaikan sebesar 0.087. Koefisien regresi Ukuran Perusahaan bernilai 0.017 yang artinya apabila variabel Profitabilitas, Leverage, Komisaris Independen dan Intensitas Modal tetap dan Ukuran Perusahaan mengalami kenaikan satu satuan maka variabel penghindaran pajak akan mengalami penurunan sebanyak 0.017. Koefisien regresi Intensitas Modal bernilai -0.0219 yang artinya apabila variabel Profitabilitas, Leverage, Komisaris Independen dan Ukuran Perusahaan tetap dan Intensitas Modal mengalami kenaikan satu satuan maka variabel penghindaran pajak akan mengalami penurunan sebesar -0.0219 .

Tabel 7

Uji F

\begin{tabular}{c|c|c|c|c}
\hline Fhitung & Ftabel & Sig. & Syarat & Keputusan \\
\hline 35.33 & 2.361 & 0.000 & $<0.05$ & Model layak \\
\hline
\end{tabular}

Sumber : data diolah (2019)

Dengan perhitungan pada tabel 7 di atas maka dapat disimpulkan bahwa nilai Fhitung > Ftabel dan nilai signifikansi sebesar < 0.05 yang berarti bahwa model kelayakan untuk menguji pengaruh variable independen terhadap variable dependen adalah layak.

Tabel 8

Uji Hipotesis 


\begin{tabular}{c|c|c|c|c|c}
\hline Hipotesis & Thitung & Ttabel & Sig. & Syarat & Keputusan \\
\hline H1 (Profitabilitas) & 1.830 & 1.669 & 0,632 & $>0.05$ & Diterima \\
\hline H2 (Leverage) & -0.830 & -1.669 & 0,009 & $>0.05$ & Ditolak \\
\hline $\begin{array}{c}\text { H3 (Komisaris } \\
\text { Independen) }\end{array}$ & 1.749 & -1.669 & 0,943 & $>0.05$ & Diterima \\
\hline $\begin{array}{c}\text { H4 (Ukuran } \\
\text { Perusahaan) }\end{array}$ & 1.790 & 1.669 & 0,904 & $>0.05$ & Diterima \\
\hline $\begin{array}{c}\text { H5 (Intenditas } \\
\text { Modal) }\end{array}$ & -.374 & -1.669 & 0,026 & $>0.05$ & Ditolak \\
\hline
\end{tabular}

Sumber : data diolah (2019)

Tabel 9

Uji Koefisien Determinasi

\begin{tabular}{c|c}
\hline Adjusted R Square & Keputusan \\
\hline 0.42 & Berpengaruh sebesar 42\% \\
\hline
\end{tabular}

Sumber : data diolah (2019)

Dari data tabel 9 di atas, angka koefisien determinasi sebesar 0.42 yang berarti $42 \%$. Variabel penghindaran pajak mampu dijelaskan oleh variabel profitabilitas, leverage, komisaris independen, ukuran perusahaan dan intensitas modal. Untuk $58 \%$ sisanya, variabel penghindaran pajak mungkin mampu djelaskan oleh proksi variabel yang lainnya di luar dari variabel pada penelitian ini.

\section{Pengaruh Profitabilitas Terhadap Penghindaran Pajak}

Berdasarkan pengujian yang telah dilakukan, hasil penelitian profitabilitas menunjukkan bahwa profitabilitas berpengaruh signifikan terhadap penghindaran pajak. Penelitian ini sejalan dengan penelitian yang dilakukan Tawang (2017), Anisa et al (2017) dan Ariawan dan Setiawan (2017) yang menunjukkan bahwa profitabilitas yang diproksikan oleh ROA tidak berpengaruh terhadap penghindaran pajak.

Namun penelitian tersebut tidak sejalan dengan penelitian Maharani dan Suardana (2014) dan Utari dan Supadmi (2017) yang menunjukkan bahwa profitabilitas tidak berpengaruh terhadap penghindaran pajak. Penelitian ini menunjukan hasil yang berpengaruh negatif signifikan, karena profitabilitas merupakan variabel yang diduga dapat menjelaskan adanya aktivitas penghindaran pajak yang dilakukan perusahaan.

Menurut penelitian Maharani dan Suardana (2014) perusahaan yang memperoleh laba diasumsikan tidak melakukan penghindaran pajak dikarenakan perusahaan mampu mengatur pendapatan yang diperoleh dan pembayaran pajaknya.

\section{Pengaruh Leverage Terhadap Penghindaran Pajak}


Berdasarkan pengujian yang telah dilakukan, hasil penelitian ini menunjukkan bahwa leverage tidak berpengaruh terhadap penghindaran pajak. Pelelitian ini sejalan dengan penelitian yang dilakukan Irianto et al (2017) dan penelitian Putra dan Merkusiwati (2016), dan Arianandini dan Ramantha (2018) yang menyatakan bahwa leverage tidak mempengaruhi penghindaran pajak.

Namun tidak sejalan dengan Anisa et al (2017) yang menyebutkan bahwa leverage berpengaruh terhadap penghindaran pajak. Leverage tidak bepengaruh hal ini terjadi dikarenakan semakin tinggi tingkat hutang suatu perusahaan maka pihak manajemen akan lebih konservatif dalam melakukan pelaporan keuangan atau operasional perusahaan. Pihak manajemen akan lebih berhati-hati dan tidak akan mengambil resiko yang tinggi untuk melakukan aktivitas penghindaran pajak guna menekan beban pajaknya. Apabila hutang digunakan dalam jumlah yang besar maka dapat menimbulkan kerugian bagi perusahaan.

\section{Pengaruh Komisaris Independen Terhadap Penghindaran Pajak}

Komisaris independen tidak berpengaruh terhadap penghindaran pajak. Penelitian ini sejalan dengan penelitian yang diakukan Titisari dan Mahanani (2017) dan penelitian Ariawan dan Setiawan (2017) yang meyatakan komisaris independen tidak berpengaruh terhadap penghindaran pajak.

Penelitian ini tidak sejalan dengan Putra dan Merkusiwati (2016) yang menunjukkan bahwa komisaris independen berpengaruh terhadap penghindaran pajak. Penelitian ini tidak berpengaruh, karena semakin banyak jumlah komisaris independen maka semakin besar pengaruhnya untuk melakukan pengawasan kinerja manajemen yang semakin baik. Dengan adanya pengawasan, manajemen akan berhati-hati mengambil keputusan dalam menjalankan perusahaan.

\section{Pengaruh Ukuran Perusahaan Terhadap Penghindaran Pajak}

Berdasarkan pengujian yang telah dilakukan, hasil penelitian menunjukkan bahwa ukuran perusahaan berpengaruh negatif secara signifikan terhadap penghindaran pajak. Penelitian ini sejalan dengan penelitian yang dilakukan Munandar et a (2016) dan Putra dan Merkusiwati (2016). Namun tidak sejalan dengan penelitian Titisari dan Mahanani (2017) yang menunjukkan bahwa ukuran perusahaan tidak berpengaruh terhadap penghindaran pajak.

Penelitian ini menunjukkan hasil berpengaruh negatif secara signifikan. Hal ini dapat terjadi karena semakin besar aset yang dimiliki perusahaan maka semakin besar ukuran perusahaan dan jika semakin besar ukuran perusahaan, maka akan berdampak pada menurunnya besaran penghindaran pajak. Sebaliknya, semakin kecil nilai ukuran perusahaan maka akan berdampak pada meningkatnya besaran penghindaran pajak.

\section{Pengaruh Intensitas Modal Terhadap Penghindaran Pajak}

Berdasarkan pengujian yang telah dilakukan, hasil penelitian intensitas modal menunjukkan bahwa intensitas modal tidak berpengaruh terhadap penghindaran pajak. Penelitian ini sejalan dengan penelitian yang dilakukan Muzzaki dan Darsono (2015) dan Irianto et al (2017) yang 
menunjukkan bahwa intensitas modal tidak berpengaruh terhadap penghindaran pajak. Namun tidak sejalan dengan penelitian Anindyka et al (2018) yang menunjukkan intensitas modal berpengaruh terhadap penghindaran pajak. Penelitian ini menunjukkan hasil tidak berpengaruh. Hasil tersebut menunjukkan bahwa penyusutan atas kepemiikan aset tetap tidak memberikan efek yang cukup besar dalam hal mengurangi pembayaran pajak oleh perusahaan. Intensitas modal yang tinggi dilakukan oleh sebuah perusahaan tidak semata-mata untuk menghindari pajak melainkan dilakukan oleh perusahaan untuk tujuan menjalankan operasi perusahaan Dharma dan Ardiana (2016).

\section{Kesimpulan dan Saran}

\section{Kesimpulan}

Berdasarkan hasil analisis data mengenai pengaruh profitabilitas, leverage, komisaris independen, ukuran perusahaan dan intensitas modal terhadap penghindaran pajak. Dengan menggunakan data 23 perusahaan property dan real estate yang terdaftar di Bursa Efek Indonesia (BEI) periode tahun 2016-2018 yang sudah memenuhi kriteria sampel dalam penelitian ini. Penelitian ini menggunakan teknik analisis regresi liner berganda dengan hasil profitabilitas dan ukuran perusahaan, berpengaruh negatif terhadap penghindaran pajak serta leverage, komisaris independen dan intensitas modal tidak berpengaruh terhadap penghindaran pajak.

\section{Keterbatasan}

1. Populasi yang digunakan dalam penelitian ini adalah perusahaan property dan real estate yang terdaftar dalam Bursa Efek Indonesia. Sedangkan data perusahaan yang terdaftar dalam Bursa Efek Indonsia sangat beragam.

2. Variabel yang digunakan dalam penelitian ini hanya profitabilitas, leverage, komisaris independen, ukuran persahaan dan intensitas modal. Sedangkan masih banyak variabel lain yang berpengaruh terjadap penghindaran pajak.

\section{Saran}

1. Penelitian selanjutnya diharapkan dapat mempertimbangkan perusahaan yang akan dijadikan populasi dan memperluas sampel penelitian selain perusahaan property dan real estate yang terdaftar di Bursa Efek Indonesia, agar dapat memperkuat kesimpulan yang dihasilkan dalam penelitian tersebut.

2. Bagi peneliti selanjutnya diharapkan dapat menambah variabel yang akan digunakan seperti komite audit, kualitas audit, kepemilikan institusional, umur perusahaan dan sales growth, agar hasil dari penelitian tentang penghindaran pajak lebih bervariasi. 


\section{Daftar Pustaka}

Anindyka S , D., Pratomo, D., \& kurnia. (2018). Pengaruh Leverage (DAR), Capital Intensity Dan Inventory Intensity Terhadap Tax Avoidance (Studi Pada Perusahaan Makanan dan Minuan di Bursa Efek Indonesia (BEI) Tahun 2011-2015). e-Proceeding of Management, Vol.5, No.1, 713.

Ardi, M. S., \& Lana, S. (2007). Pengaruh Ukuran Perusahaan, Profitabilitas, Leverage, Kepemilikan Perusahaan Terhadap Luas Voluntary Disclosure Laporan Keuangan Tahunan. Proceeding PESAT, Volume 2.

Darmawan, I. H., \& Sukartha, I. M. (2014). Pengaruh Penerapan Corporate Governance, Leverage, Return On Assets, Dan Ukuran Perusahaan Pada Penghidaran Pajak. E-Jurnal Akuntansi Universitas Udiyana, 143- 161.

Iman, S., \& Ning, R. (2013). Corporate Tax Management: Mengupas Upaya Pengeluaran Pajak Perusahaan Secara Konseptual. Ortax.

Kurniasih, Tommy, \& Sari. (2013). Pengaruh Return On Assets, Leverage, Corporate Governance, Ukuran Perusahaan dan Kompensasi Rugi Fiskal Pada Tax Avoidance. Dalam Buletin Studi Ekonomi, Volume 18 No.1.

Maharani, I. C., \& Suardana, K. A. (2014). Pengaruh Corporate Governance, Profitabilitas Dan Karakteristik Eksekutif Pada Tax Avoidance Perusahaan Manufaktur. E-jurnal Akuntansi Universitas Udayana, 525- 539.

Milhanudin, A. (2017). Analisis Pengaruh Komisaris Independen, Kompensasi Rugi Fiskal, Leverage, Profitabilitas, dan Ukuran Perusahaan Terhadap Tax Avoidance (Studi Empiris pada Perusahaan Manufaktur yang Terdaftar i Bursa Efek Indonesia Periode 2012-2015.

Putra, I. C., \& Merkusiwati, N. A. (2016). Pengaruh Komisaris Independen, Leverage, Size Dan Capital Intensity Ratio Pada Tax Avoidance. EJurnal Akuntansi Universitas Udayana, 690- 714.

Rachmithasari, \& Annisa, F. (2015). Pengaruh Return On Assets, Leverage, Corporate Governance, Ukuran Perusahaan dan Kompensasi Rugi Fiskal Pada Tax Avoidance. Skripsi Universitas Muhammadiyah Surakarta.

Rodriguez, \& Arias. (2013). Do Business Characteristics Determine an Effective Tax Rate?. The Chinese Economy,, Vol 45 (6), , 60-83. 
Surbakti, T. (2012). Pengaruh Karakteristik Perusahaan Dan Reformasi Perpajakan Terhadap Penghindaran Pajak di Perusahaan Manufaktur. Skripsi Universitas Indonesia.

Waluyo. (2011). Perpajakan Indonesia. Jakarta: Salemba Empat.

Wijayanti, \& Ibnu. (2014). "Mengenal Penghindaran Pajak, Tax Avoidance.". 